\title{
THE IMPLEMENTATION OF VIDEO IN TEACHING LISTENING
}

\author{
Astri Nur Utari ${ }^{1}$ and Vina Nurviyani ${ }^{2}$ \\ Suryakancana University \\ astrinutari@gmail.com VinaNurviyani@unsur.ac.id
}

\begin{abstract}
According to Meyer (2002) in Muniandy and Veloo (2011:173; cited in Tugiwati, 2014) defines video as a kind of multimedia material consisting of verbal and non-verbal presentations displaying simultaneous images, narration and on screen text. Video is an electronic device that produces live images with a sounds. The major goals of this study were to investigate the implementing of video in teaching listening, the object of this study is the second grade students in senior high school. This study employed a classroom action research. Classroom action research on this study was conducted in two cycles. There are four steps in each cycle; planning, action, observation, and reflections. The data of this study were analyzed by using mix method, both of quantitative and qualitative. For quantitative method, the researcher used test to collect the data. While for qualitative method, it was analyzed by using questionnaire and observation. The test is used by the researcher to measure student's listening skill improvement. In each cycle the researcher conducted pre-test and post-test. The questionnaires were used to support the data. Observation was used to evaluate the learning processes. The results show that the use of video in teaching listening was success to improve students' achievement. It can be seen from the result of each test in each cycle. In cycle 1 the mean scores of pre-test 1 was 53.06, post-test 1 was 57.83. While in cycle 2, pre-test 2 was 71.94, post-test 2 was 75.81 . The result of questionnaires shows that the students could understand the content of the video easily. The result of observation showed that video could create fun learning.
\end{abstract}

Keywords: listening, video, teaching listening, teaching listening through video 


\section{INTRODUCTION}

Many students have difficulties in studying English, especially in listening comprehension. The students think that listening is the hardest part in learning English. However, the goal of teaching English at the school is to make the students master the four language skills. They are reading, writing, speaking, and listening. Listening is one of English skills that should be mastered by the students. But in reality, the ability of students' listening skill still are low. In English subject, listening skill is important to make the students familiar with the English words. Field (2009; cited in Kamilah, 2013) stated that students may have more abilities to communicate well with others if they have a good listening skill.

Listening problem are caused by some factors. One of factors is the implementation of media for teaching listening that the teacher used. Most teachers used conventional media in teaching listening. So that there is no attractive media to make students familiar with the native sounds. To make the student familiar with English words, the teacher only use conventional strategies by dictation. It makes the students are difficult to catch what they hear.

However the study of teaching listening by using video in senior high school is still rare. This study investigated the implemention of video in teaching listening. Besides, it explored the strength and the weakness of implementing video in teaching listening.

The result of this study is expected can give good contribution for both of further teaching learning process and further research.

\section{THEORETICAL FRAMEWORKS}

Listening is one of English skill that should be mastered by the students. Listening is receiving language through the ears. Listening involves identifying the sounds of speech and processing them into words and sentences. When we listen, we use our ears to receive individual sounds (letters, stress, rhythm and pauses) and we use our brain to convert these into messages that mean something to us. Listening is a natural process in acquiring a new language. According to Underwood (1989; cited in Woottipong, 2014), a child receives a large amount of verbal input through listening prior to developing speaking, writing and 
reading skills. These skills are developed later as the child matures. We can distinguish two broad types of listening (Nation and Newton. 2009:40): 1) One-way listening- typically associated with the transfer of information (transactional listening); 2) Two-way listeningtypically associated with maintaining social relation (interactional listening).

Video are capable to displaying the images and sound on televisi on so that we are able to capture what is displayed by the video. Teaching and learning activities using the video will increase the success rate of delivery of material and reinforce appreciation of learners and facilitate the development of materials to what is taught. Moreover, according to Harmer (2001:284; cited in Tugiwati, 2014), there are three basic types of videos which can readily be used in class: 1) Off-air programes, for example: programes recorded from a television channel. This video can be used for a range of activities including prediction, cross culture awareness, and teaching language. However, some off-air video is extremelydifficult for the students to understand; 2) Real-world videos, for example: films, comedy, and wildlife documentaries. The teachers need to make their choice based on how engaging and comprehensible the extract is likely to be; 3) Language learning videos, or example: videos to company course books. The advantage of the videos is that they have been designed with students at a particular level in mind. However, the situations and the language are inauthentic.

According to Sulistyanto (2015) stated video is important tool for students' life in the classroom. Watching a video in lesson in quite different from watching television program for killing free time or relaxing at home; where the teacher facilitate the activities and exercise that supports the students to be more attractive and understand the video. Video provides new vocabulary, structure and function which can increase the basic skill of language learners. With the combination of audio and visual can make understandable runs well. The visuals help students understand the situation well.Video as media in teaching listening can helped teacher to deliver the material in teaching learning activity. Video can attract the students' interest in learning listening in the classroom it can help to improve students' listening skill. Because, from video they can get sound what they can hear. From video the students can provides new vocabulary. 


\section{METHOD}

This study employed a classroom action research. According to Burns (2010; cited in Tugiwati, 2014), classroom action research mainly aims to solve the problems of the teaching and learning process. Classroom action research on this study was conducted in two cycles. There are four steps in each cycle; planning, action, observation, and reflections. The data of this study were analyzed by using mix method, both of quantitative and qualitative. The researcher used three instruments for collecting the data namely test, questionnaires and observation. For quantitative method, the researcher used test to collect the data. While for qualitative method, it was analyzed by using questionnaires and observation. The test is used by the writer to measure student's listening skill improvement. There are four tests conducted to get the data about the students' progress in teaching listening through video namely Pre-Test 1 and Post-Test 1 in cycle 1 and Pre-Test 2 and Post-Test 2 in cycle 2. It was used to measure students' achievement after the whole treatment. Both of pre-test and post-test in each cycle, it consisted of 20 questions.

After conducted the test the researcher conduct the questinnaires. The questionnaires used to support the data from the test and were employed to explore the answer of the second research question concerning the strength and weaknesses in implementation of video in teaching listening. This study used open-ended questionnaire. The questionnaire consisted of 11 questions and it was distributed after the whole cycle. The question is about all of information related to the strengths and the weaknesses of the implementing video through video and the suggestion from students to the teacher to better for next teaching learning activities.

Besides conduct the test and questionnaires the researcher also conduct obervations during the learning activity. According to Burns (1999:80; cited in Kusumayati, 2010) stated that observation is taking regular conscious notice of classroom action and occurrences, which are particularly relevant to the issues or topics being investigated. In other words, observation is one of aim the observation to evaluate the learning process. There was a field note that used to observe the students' activities. This research was conducted from April until May 2010. It included pre-test and post-test in 
cycle 1 and pre-test and post-test cycle 2 that were conducted for three weeks.

The data analyses were conducted to answer all research questions. The data obtained test, open-ended questionnaires, and classroom observations were analyzed, categorized, and then interpreted into three themes based on the research questions. Data collection from tests and questionnaire were analyzed by using mix method. Test was analyzed by quantitative method. While observation was analyzed by qualitative method. Both of them were used to measure the students' improvement before and after giving treatment

\section{FINDINGS AND DISCUSSION}

\section{The Effect of Using Video in Teaching Listening}

This stage presents the data collection from tests. Tests were done by conducting classroom action research. There were four tests, namely pre-test 1 , post-test 1 , pre-test 2 , and post-test 2. It was got through cycle 1 and cycle 2. Arikunto (1998:51; cited in Khasanah, 2011) suggest that test is a set of question or exercises or other instrument used to measure the individuals or group skills, knowledge, intelligence, ability or attitude of group or individual.

Analyzing the result of tests, the mean score of the pre-test 1 was 53,06 and the mean score of pos-test 1 was 57,83 . While the result of mean score in post-test 1 was 57.83. It was still lower than KKM. The result of mean score was under 75. But it increased from the mean score of pre-test 1 which was 53.06 and it increased 4.77 point. Then in the cycle 2, the result of mean score in pre-test 2 was 71.94. It was still lower than KKM, but it improved from the result of mean score in cycle 1 . While the result of mean score in post-test 2 was 75.81. It had achieved KKM. It increased from the mean score of pre-test 2 which was 71.94. The improvement of mean score from pre-test 2 to post-test 2 was 3.87 point. On the other hand, the implementation of video in teaching listening was success to improve students' listening skill.

From the data findings above, the use video in teaching listening was success to improve students' achievement. It can be seen from the result of each test in each cycle. In cycle 1 the mean scores of pre-test 1 was 53.06, post-test 1 was 57.83 . While in cycle 
2, pre-test 2 were 71.94, post-test 2 was 75.81 .

According to Sulistyanto (2015) video provides new vocabulary, structure and function which can increase the basic skill of language learners. In this case, the students' listening skill increased. It indicated that implementation of video helped the students to catch the content of the video. Because of by using video, the students not only could hear the information, but also catch the facial expression. So that, it eased the students to understand what was happened on the video.

\section{Strengths and Weaknesses Teaching Listening through Video}

In this stage, the researcher used open-ended questionnaire and observation to answer the second research question about the strengths and weaknesses teaching listening through video.

Brown (2001: 6 cited from Dornyei, 2003: 6; in Nurviyani, 2014) states that questionnaires are any written instruments that present respondents with a series of questions or statements to which they are to react either by writing out their answers or by selecting from among existing answers. The data finding from questionnaire showed the strengths and the weaknesses of implementing video. Below the result of students' questionnaire from the general students' answer. Below is the result of questionnaires that the researcher found concerning the strengths and weaknesses of implementing video.

Table 4.5 The Result of Students' Questionnaire

\begin{tabular}{|c|l|l|}
\hline No & Strength & Weakness \\
\hline 1 & $\begin{array}{l}\text { The students could understand the content of } \\
\text { the video. }\end{array}$ & The sound was too fast; \\
\hline $\mathbf{2}$ & $\begin{array}{l}\text { It was interesting because they can listen } \\
\text { while watching video. }\end{array}$ & $\begin{array}{l}\text { Students focus on video } \\
\text { rather than listen the } \\
\text { video. }\end{array}$ \\
\hline $\mathbf{3}$ & It did not make students bored & The sound was not clear; \\
\hline $\mathbf{4}$ & It can motivated the students & \\
\hline $\mathbf{5}$ & They could know how to pronounce well & \\
\hline
\end{tabular}


The result of observation showed that video could create fun learning. It made the students more enjoyable in joining the lesson. In line with Tugiwati (2014) stated that the various activities in implementing made the class atmosphere enjoyable so the students' motivation in learning English improved. Below is the result of observation that the researcher found concerning the strengths and weaknesses of implementing video.

Table 4.6 The Result of Observation

\begin{tabular}{|l|l|l|}
\hline No & Strength & Weakness \\
\hline 1 & $\begin{array}{l}\text { Video made the students enthusiast in joining } \\
\text { the lesson }\end{array}$ & $\begin{array}{l}\text { Students focus on video } \\
\text { rather than listen the } \\
\text { video. }\end{array}$ \\
\hline $\mathbf{2}$ & Implementing video created fun learning & $\begin{array}{l}\text { If the class was noisy, } \\
\text { the sounds was not clear }\end{array}$ \\
\hline $\mathbf{3}$ & It did not make students bored & \\
\hline
\end{tabular}

Based on the result of classroom observation above, the implementing video made students enthusiast in joining the lesson. The students are enthusiastiq by asking what the video that would be showed. They always waited what the video that would be showed. When the teacher did not showed the video, the students complained toward it.

\section{CONCLUSION}

From the study, it can be concluded that the implementation of video in teaching listening was success to improve students' listening skill. this study employed a classroom action research. From the data findings of this study, the use video in teaching listening was success to improve students' achievement. It can be seen from the result of each test in each cycle. In cycle 1 the mean scores of pre-test 1 was 53.06, post-test 1 was 57.83. While in cycle 2 , pre-test 2 were

71.94, post-test 2 was 75.81 .

Through video, the students could understand the content of the video easily, even 
though they could not understand what the speaker said. Because of through audio visual, the students not only listened but also watched the situation on the video. By watching video, it makes the students interest to the learning activity, because they can listen while watching video. But, sometime implementing video made the students prefers to watch rather than listen. It made them focus on the content than the sounds that they listened.

By watching video, the students could imitate what the speaker said. They could know how to pronounce well. Regarding the first research question, this research found that the students' achievement in listening video improved. While, regarding the second research question and observation, the researcher found that there were some strengths and weakness of implementing video in teaching listening.

\section{REFERENCES}

Kamilah, M. (2013). The Use of Contextual Video to Improve Students' Listening Ability. English Education Study Program of Indonesia University of Education, Journal of English and Education 2013, 1(1) 122-132. Retrieved

on May 26 $6^{\text {th }}$, 2016. From: http://webcache.googleusercontent.com

Khasanah, U. (2011). Improving Listening Skill Through Storytelling. Salatiga: State Islamic Studies Insitute. Retrieved on June $26^{\text {th }}$, 2016. From: http://perpus.iainsalatiga.ac.id/docfiles/fulltext/2dbdcdbe1fafdf3f.pdf

Kusumayati, L. D. (2010). Improving Students' Vocabulary Mastery Using Contextual Teaching and Leaning. Surakarta: Universitas Sebelas Maret. Retrieved on June $9^{\text {th }}$, 2016. From: https://core.ac.uk/download/pdf/12348780.pdf

Nation, I. S. P. and Newton, Jonathan. (2009). Teaching ESL/EFL Listening and Speaking. Routledge: New York.

Nurviyani, V. (2014). The English Teachers' Understanding of Genre Based Approach: Application and Difficulties in Teaching-Learning Activities. Bandung: Indonesia University of Education.

Sulistyanto, Irwan. (2015). Teaching Listening at The Second Grade of SMAN 1 Karangrejo. Retrieved on June $9^{\text {th }}$, 2016. From: https://www.academia.edu/15059753/Teaching_Listening_Journal

Tugiwati, D. (2014). The Use of Video to Improve the Listening Skills. (Thesis, English Education Department, Faculty of Language and Arts, Yogyakarta State University, 2014). Retrieved on March $31^{\text {th }}, 2016$. From:http://eprints.uny.ac.id/18508/1/Dwi\%20Tugiwati\%2009202241029.pdf

Woottipong, K. (2014). Effect of Using Video Materials in the Teaching Listening Skills for University Students. International Journal of Linguistics ISSN 1948-5425 2014, Vol. 6, No. 4. Retrieved on January $1^{\text {th }}, 2016$. From:http://www.macrothink.org/journal/index.php/ijl/article/viewFile/5 $\underline{870 / p d f \_125}$ 
